Univerzita Mateja Bela

v Banskej Bystrici

alena.zaborska@umb.sk

\title{
MULTIKULTÚRNOSŤ AKO ZDROJ HUMORU Z POHLADU ONOMASTIKY
}

Kl’úč o vé s lová: multikultúrnost', stereotyp, etnický humor, etnonymum, antroponymum

\section{ÚVOD}

Ciel'om príspevku je analyzovat' postavenie proprií v etnickom humore, ktorý ako jeden z etnických determinantov ilustruje rozdiely medzi vlastným spoločenstvom a cudzími spoločenstvami. Humor vo všeobecnosti má rôzne podoby, no my sme pracovali so slovenskými vtipmi a anekdotami s etnicitou, resp. s etnickým komponentom, ktorých vznik možno považovat' za sprievodný jav multikulturalizmu a globalizácie l’udskej spoločnosti. Ako špecifické formy humoristického zamerania vyznačujúce sa jednoduchost’ou, pohotovost’ou, dvojzmyselnost'ou a nápovednost'ou sú vtipy a anekdoty výstižným a sociálne akceptovatel'ným nástrojom pranierovania spoločenských skupín a l’udských charakterov (Harpáň 2004). V tomto duchu interetnické vzt’ahy a s nimi súvisiaci stret rozmanitých sociokultúrnych skupín a ich členov s charakteristickými vlastnost’ami predstavujú bohatý zdroj humoru založeného na interetnickej komparácii. Výskumný materiál sme čerpali zo slovenských zbierok vtipov a internetových stránok.

\section{KULTÚRA A MULTIKULTÚRNOSŤ}

Napriek existencii viacerých interpretácií možno vo všeobecnosti kultúru považovat' za nevrodený a jedinečný súbor istých viac i menej viditel'ných determinantov, ktoré sa postupne kryštalizovali vplyvom historických, geografických, spoločenských, politických a d'alších faktorov pôsobiacich na dané spoločenstvo. Ako uvádza A. Kačmárová (2011), medzi viditel'né prvky istej kultúry patrí okrem jazyka napr. hudba, literatúra, oblečenie a iné artefakty a produkty l'udskej činnosti, ktoré má člen cudzej kultúry možnost' bezproblémovo pozorovat'. Väčšie t’ažkosti pramenia zo skrytých, resp. menej viditel'ných determinantov súvisiacich so zafixovanými vzormi správania, postoj- 
mi, hodnotami a pod. Jedine oboznámením sa s oboma uvedenými zložkami kultúry môže človek predíst' kultúrnemu šoku a kultúrnemu nedorozumeniu.

Pre súčasnú spoločnost' je príznačná kultúrna diverzita a pluralita, atribúty typické pre multikultúrnu spoločnost'. Tá predstavuje „súžitie odlišných etnických, jazykových, náboženských či národných minorít s majoritnou spoločnost'ou v rovnakom čase i priestore“ (Darulová, Koštialová 2010: 46). Spolužitie viacerých etník a kultúr často vedie $\mathrm{k}$ vzniku etnostereotypov, teda predstáv a predsudkov jednej skupiny l'udí o iných skupinách. V pozadí vzniku a šírenia etnostereotypov stojí etnocentrizmus, čiže tendencia nazerat' na cudzie kultúry cez prizmu hodnôt, postojov a noriem vlastnej kultúry. Etnocentrické nazeranie na iné etniká umocňuje porovnávanie medzi „tým naším“, ktoré je zvyčajne v očiach primárneho etnika lepšie, a „tým cudzím“. Takáto komparácia tvorí základ etnostereotypov, a tak v dôsledku nadrad'ovania vlastnej kultúrnej a životnej úrovne upevňujú etnocentrické sklony v povedomí členov etník vzájomné rozdiely.

Multikultúrnost' má rôzne pozitívne konzekvencie, ako napr. zrovnoprávňovanie etnických skupín a vzájomné kultúrne obohacovanie. V dôsledku nedostatočnej akceptácie rôznorodosti a neuznávania právoplatnosti iných kultúr však môže spolužitie spoločenstiev viest' i k negatívnym dôsledkom (Mistrík 1999), a to ku xenofóbii, kultúrnej asimilácii a univerzalizácii a pod. Za vonkajšie prejavy multikultúrnosti a multietnicity možno považovat' koexistenciu viacerých úradných jazykov, označovanie obcí v jazyku národnostných menšín a iné javy. Multikultúrnost' má svoj odraz i v humore a vo vtipoch.

\section{PROPRIÁ V ETNICKÝCH VTIPOCH}

Ako uvádza J. Glovňa (2015b), vo všeobecnosti môžeme rozlíšit dve skupiny vtipov — vecné vtipy reflektujúce komické, zvyčajne nadkultúrne situácie a slovné vtipy, ktorých pointa je spätá so špecifickými vlastnost’ami istého jazyka. Ciel’om etnického humoru ako kultúrne špecifického javu podnieteného o. i. multikultúrnost’ou je „okrem upevnenia skupinového usporiadania, súdržnosti a spoločenskej hierarchie, taktiež narušenie egality, podpora nepriatel'stva či sociálnej kontroly cez výsmech a zosmiešnenie charakteristík iných etnických skupín na základe špecifických biologických znakov, správania či kultúry“ (Gogová 2013). Etnické vtipy teda reflektujú kultúrne, jazykové a rasové rozdiely medzi jednotlivými etnikami vyplývajúce zo vzájomného kontaktu.

V príspevku prezentovanom na medzinárodnej slavistickej konferencii v Bratislave sme poukázali na tri základné tematické okruhy etnických vtipov. Prvá skupina vtipov odráža jazykové odlišnosti vybraných etník. Druhá skupina zobrazuje aktuálnu alebo historickú situáciu etnika, vd'aka čomu tieto vtipy možno považovat' za súčast' kolektívnej pamäti danej sociokultúrnej skupiny. V tretej skupine je pointa vtipu 
spätá s reflexiou etnostereotypov. Vo všetkých typoch etnických vtipov je kl'účové hl'adisko etnika, ktoré daný vtip prezentuje (Záborská 2016).

V uvedených tematicky odlišných typoch etnických vtipov sa súvislost's konkrétnym etnikom vyjadruje rôznymi spôsobmi. Vo vtipoch reflektujúcich jazykové odlišnosti sa na dané etnikum explicitne poukazuje väčšinou prostredníctvom označenia jazyka.

— Viete, ako sa povie po pol'sky prasa?

- Dobrota zabijačkowa ${ }^{1}$.

Etnickú príslušnost' postáv vystupujúcich v etnických vtipoch môžeme naznačit' použitím špecifických jazykových prostriedkov (napr. slovo v jazyku daného etnika). V nasledujúcom vtipe mad'arskú etnicitu naznačujú osobité gramatické tvary slovenčiny, ktoré Slováci stereotypne spájajú s Mad’armi hovoriacimi po slovensky. Okrem t'ažkostí s flexiou možno v ich jazykovom prejave badat' absenciu zvratných zámen $s a$ a si, čo je viditel'né aj v prehovore zdravotnej sestry v uvedenom vtipe ${ }^{2}$, ktorého humorná pointa je výsledkom zámeny slovies stat'sa — stát'. Kontext dotvára i urbanonymum Nové Zámky označujúce slovenské mesto s mad'arskou národnostnou menšinou.

Ráno hlási sestrička primárovi stav pacientov v nemocnici v Nových Zámkoch:

— V noci všetci dobre cítili, nikom nič nestálo! ${ }^{3}$

Etnickú príslušnost’ zobrazujú i vlastné mená. Primárne ide o dve skupiny proprií - etnonymá a antroponymá.

E tn o n y má. Azda najjednoduchší a najzretel'nejší spôsob naznačenia etnickej príslušnosti vystupujúcich postáv je využitie etnoným, čiže vlastných mien etník alebo členov etník. Etnonymá evokujú konotácie späté so zástupcami daného etnika - často ide práve o etnostereotypy, ktoré v mnohých prípadoch navyše podčiarkuje pointa vtipu. $\mathrm{V}$ dôsledku zobrazovania komických situácií v realite majú tieto vtipy charakter vecných vtipov, no reflexia etnostereotypov spôsobuje, že nemajú nadkultúrny ráz ${ }^{4}$. V nasledujúcom vtipe sa pointa opiera o stereotyp o Židoch ako lakomých a šetrných l’udí, na ktorý formálne odkazuje etnonymum Žid. V slovenčine je táto súvislost' prítomná i v deproprializovanom tvare židák.

Príde Žid do neba a búcha na nebeskú bránu. Otvorí svätý Peter a pýta sa:

— Čo chceš, Žid?

— Chcel by som sa, prosím, porozprávat's Ježišom.

${ }^{1} \mathrm{http} / / /$ vtipy.zabinudu.sk/kategoria/polske-vyrazy/2

2 Jazykovo korektná podoba vety je „V noci sa všetci dobre cítili, nikomu sa nič nestalo“.

${ }^{3} \mathrm{http}: / /$ www.seniorhumor.org/?page_id=192

${ }^{4}$ O nadkultúrnom, resp. nadetnickom ráze vtipu reflektujúceho etnostereotyp by sme mohli uvažovat' v prípade, že daný etnostereotyp je prítomný pri viacerých etníkách. 
Svätý Peter na to:

- A čo, chceš ho poprosit' o odpustenie, že ste ho ukrižovali?

— Nie, on nám totiž ešte nezaplatil za poslednú večeru (Špet'ko 2009: 295).

Ako uvádza L. Garančovská (2012), etnostereotypy sú v jazykovej praxi popri etnonymách späté i s deetnonymami, čiže s apelativizovanými etnickými názvami. Významová súvislost' deetnoným s etnonymami môže byt' rôzna, na čo poukazuje i M. Košková (2006). Existujú totiž deetnonymá bez odrazu konotácií spätých s etnonymami — takéto deetnonymá signalizujú napr. pôvod alebo výskyt denotátus. V druhej skupine deetnonymá „rozvíjajú prenesené významy aj na základe istých typických alebo prisudzovaných vlastností príslušníkov národov alebo etnických skupín, ktoré pomenúvajú“ (Košková 2006: 21). V tomto zmysle máme v lexikálnom systéme slovenčiny zakotvených niekol'ko deetnoným, ktoré odrážajú predovšetkým negatívne vlastnosti a prejavy príslušníkov národov alebo etnických skupín, napr. škót, žid (obe vo význame 'lakomec, skupáń'), cigán (vo význame 'klamár') a talian (vo význame ‘človek, s ktorým sa nedá dohovorit”). Vychádzajúc z náhl'adov J. Glovňu (2015a) na využitie vlastných mien vo frazeologizmoch možno tvrdit', že deetnonymá vznikajú zmenou sémantických a formálnych vlastností, a to najmä stratou identifikačnej funkcie proprií, ktorá nastáva pri vstupe propria do frazémy. V dôsledku toho dochádza k apelativizácii (lakomý ako Škót > škót). Vd’aka svojim reflexiám etnostereotypov možno tieto deetnonymá nájst' vo vtipoch. Pointa nasledujúceho vtipu je výsledkom kalambúrnej kontaminácie, slovnej hry tvoriacej základ viacerých frazeologizmov obsahujúcich propriálnu zložku. Jej vznik podl’a J. Krška „vyplýva z napätia medzi prvoplánovým propriom a druhoplánovým (frazeologickým) apelatívom“ (2008: 262). Pointa vtipu je teda odrazom rozporu medzi propriálnou a apelatívnou rovinou.

Dvaja Škóti sa prechádzajú po lese, pričom John povie Bobbymu, že musí íst' na vel'kú potrebu.

Bobby mu poradí, aby išiel za strom. Za chvílu John kričí spoza stromu:

- Bobby, nemáš u seba papier?

— Nebud' už taký škót a nechaj to tam .

Etnonymá sa nachádzajú i vo vtipoch bez reflexie etnických stereotypov. V takých vtipoch možno dané etnonymá vzájomne zamenit' alebo úplne vymenit', lebo vlastnosti a konanie danej postavy sa neviažu ku konkrétnemu etniku. Vd’aka tomu sa zmenou etnoným humorná pointa nestráca ani nemení, lebo je zakotvená v inom mimojazykovom aspekte. V dôsledku absencie väzby medzi vtipom a etnikom možno taký druh vtipov zaradit' $\mathrm{k}$ vecným vtipom s nadkultúrnym rázom, ktorých podobnost' $\mathrm{s}$ etnickými vtipmi v pravom zmysle slova je čisto formálna, vyplýva z využitia etnoným.

\footnotetext{
${ }^{5}$ Napr. španielka označujúca druh chrípky, ktorá sa rozšírila zo Španielska.

${ }^{6} \mathrm{http}: / / \mathrm{www}$. smiechoty.sk/vtipy/cudzinci/5/
} 
Slováka, Mad'ara a Rusa chytia Indiáni. Chcú z ich kože spravit' kanoe, ale dovolia im želat' si ešte niečo pred smrt'ou. Mad'ar si teda želá alkohol. Napije sa a potom ho stiahnu z kože a urobia z neho kanoe. Rus si želá marihuanu. Nakúri sa a aj z toho spravia kanoe. Posledný ide Slovák. Ten si želá vidličku. Nikto nechápal na čo, no nakoniec mu ju dali. Ten ju zobral, dopichal sa ňou a povedal:

- A máte po kanoe! ${ }^{7}$

A n tro p o n y má. V etnických vtipoch môžu byt' členovia rozmanitých etník ako nositelia etnostereotypov formálne zastúpení i antroponymami, ktoré modelovo reprezentujú jednotlivé etniká. Opierajúc sa o tvrdenia J. Sipka (2012), antroponymá v etnických vtipoch sprostredkovane odrážajú modelové správanie sa jednotlivých etník a národov. V dôsledku toho nadobúdajú charakter lingvokulturém ako formálnych jednotiek odrážajúcich etnokultúrne konotácie. M. Košková (2006) v súvislosti s jednoslovnými výrazmi reflektujúcimi etnické koncepty s výrazným pejoratívnym nábojom používa termín etnické prezývky. Okrem využívania etnoným a deetnonymných podôb etnických prezývok na posmešné označenie iného etnika vymedzuje propriálne a metonymické etnické prezývky. Sú to vlastné mená typické pre isté cudzie etnikum, ako napr. Dežo (Róm), Ivan (Rus), Izák, Kohn (Žid), Honza, Pepík (Čech), a výrazy vyplývajúce zo špecifických jazykových, rasových alebo kultúrnych vlastností etnika, ako napr. šikmooki (príslušníci národov juhovýchodnej Ázie). V etnických vtipoch sa pre svoje etnokultúrne konotácie takéto antroponymá môžu využívat' bez explicitného etnonymického náboja, lebo sprostredkovane odkazujú na cudzie etniká. To je však možné jedine pri antroponymách, ktoré majú v povedomí recipienta silnú väzbu k istému etniku. V nasledujúcom vtipe je zobrazený slovenský stereotyp o rómskej neochote pracovat' prostredníctvom antroponyma Dežo, ktoré zastupuje rómske etnikum.

Príde utrápený Dežo k lekárovi a st’ažuje sa, že máva príšerné sny.

— O čom sa ti sníva? - pýta sa lekár.

— O robote, pán doktor, to je hrozné! (Špet'ko 2009: 181).

Ďalší vtip poukazuje na židovskú lakomost', ktorá sa spája s antroponymom Izák.

— Izák, hovoria, vraj si si ma vzal iba preto, lebo som mala vel’a peňazí!

— To nie je pravda, drahá! Bolo to naopak. Vzal som si t’a, lebo ja som ich mal vel’mi málo (Špet'ko 2009: 295).

Na zorientovanie sa v kultúrnom (a často i historickom) kontexte slúžia mená známych osobností, názvy rôznych udalostí atd’. Takéto propriá sa využívajú najmä v etnických vtipoch zobrazujúcich istú dobovú alebo aktuálnu situáciu.

\footnotetext{
${ }^{7}$ http://vtipy.4me.sk/?do=view\&id=34910
} 
Winston Churchill povedal o Kolumbovi:

Odcestoval bez toho, aby vedel, kam.

Vrátil sa bez toho, aby vedel, kde bol.

A ešte dnes musíme za jeho cestu platit' (Kalina 1991: 60).

Využitie antroponým vo vtipoch však automaticky nesignalizuje spätost's istým etnikom. V niektorých vtipoch preto nájdeme spojenie antroponyma s etnonymom, príp. toponymom, ktoré spriezračňuje extralingválnu skutočnost' v pozadí vtipu. Takýto jav sa vyskytuje zväčša pri etnicky nejednoznačných antroponymách.

Každý piaty človek na svete je Číňan. Naša rodina je pätčlenná, teda jeden z nás je Číňan. Mohol by to byt' oco, mama, môj brat Šani, malý Po-Wong alebo ja. Podl’a mňa to je Šani ${ }^{8}$.

Explicitné naznačenie etnickej príslušnosti postavy vystupujúcej vo vtipe sa nachádza aj pri osobnostiach, ktoré nie sú dostatočne známe u príslušníkov recipujúceho etnika.

Ked' krvavý španielsky hrdina maršal Narváez, vojvoda z Valencie, ležal na smrtel'nej posteli, prišiel k nemu farár.

— Pán maršal, odpustite v tejto hodine všetkým svojim nepriatel’om.

Maršal nečujne šepol:

— Nemám nepriatel'ov.

Na pochybovačný farárov pohl'ad dodal:

— Všetkých som dal zastrelit' (Kalina 1991: 58).

\section{ZÁVER}

Propriá nájdeme v rôznych vtipoch, kde plnia rozmanité funkcie. Najčastejšie majú expresívnu funkciu, vd'aka ktorej sa môže zvýraznit' vlastnost' nositel'a mena9. Expresivitu umocňuje aj účast' proprií v slovných hrách. Inokedy expresívne meno slúži výlučne na ozvláštnenie textu a na obsah vtipu sa neviaže ${ }^{10}$. Aj v etnických vtipoch možno nájst' propriá, ktoré si expedient volí s rôznymi zámermi. Jedným z nich je práve naznačenie etnickej príslušnosti postavy, na ktoré sa najčastejšie využívajú etnonymá. Etnonymá totiž umožňujú recipientovi vtipu rýchlejšie sa dostat' do kontextu, tzn. postrehnút' etniká vystupujúce vo vtipe. Vd’aka tomu sa mu rýchlejšie vybavia kultúrne, historické, jazykové a iné špecifiká daného etnika, ktoré navyše často podčiarkuje pointa vtipu. Na tento účel sa využívajú i antroponymá, no ked’že v etnických vtipoch je ich identifikačná funkcia oslabená, v mnohých prípadoch je potrebné naznačit' etnický komponent iným druhom propria. V etnických vtipoch sú etnonymá

\footnotetext{
${ }^{8} \mathrm{http} / /$ www.smiechoty.sk/vtip/6204/

${ }^{9}$ Ako príklad môžeme uviest' nasledujúce antroponymá: Ochlastová, Slopaj, Štamperlík (v̌setky naznačujú vzt’ah postavy $\mathrm{k}$ alkoholu).

${ }^{10}$ Napríklad antroponymá Tlčhuba, Trkvas, Šlamajzňa, Cickoš, Vrtinôžka atd’.
} 
a antroponymá naznačujúce etnickú príslušnost’ postavy nositel'mi etnostereotypných informácií, ktoré sa vzt'ahujú na všetkých členov daného etnika, vd’aka čomu môžeme hovorit' o synekdochickej zámene typu pars pro toto (čast' za celok).

\section{LITERATÚRA}

Darulová J., Koštialová K. 2010: Multikultúrnost’ a multietnicita, Ústav vedy a výskumu Univerzity Mateja Bela, Banská Bystrica.

Garančovská L. 2012: Od ameriky cez talianov, mad'arov, mongolov až po turecké hospodárenie (Národné stereotypy v jazykovej praxi), [v:] G. Múcsková (red.), Varia XX, Slovenská jazykovedná spoločnost' pri Jazykovednom ústave Ludovíta Štúra SAV, Bratislava, s. 153-166.

Glovňa J. 2015a: Frazeológia, Univerzita Konštantína Filozofa v Nitre, Filozofická fakulta, Nitra.

Glovňa J. 2015b: Vlastné mená vo vtipe, [v:] I. Valentová (red.), 19. slovenská onomastická konferencia, Veda, Bratislava, s. 420-423.

Gogová L. 2013: Humor na rozhrani dvoch etnicit, ,Jazyk a kultúra“, http://www.ff.unipo.sk/jak/ 15_2013/gogova.pdf (prístup 2. 11. 2016).

Harpáň M. 2004: Teória literatúry, Tigra, Bratislava.

Kačmárová A. 2011: Multikulturalita a jej sociálny rozmer, „Jazyk a kultúra“, online: http://www.ff. unipo.sk/jak/5_2011/kacmarova.pdf (prístup 28. 10. 2016).

Košková M. 2006: Etnické koncepty v jazyku (na bulharskom a slovenskom materiáli), „Slavica Slovaca" 41 , s. $17-31$.

Krško J. 2008: Napätie apelativnych a propriálnych vztahov vo frazeologizmoch, „Kultúra slova“ 42, s. 262-266.

Mistrík E. 1999: Čo je multikultúrna výchova, [v:] E. Mistrík, S. Haapanen, H. Heikkinen, R. Jazudek, N. Ondrušková, R. Räsänen, Kultúra a multikultúrna výchova, IRIS, Bratislava, s. 112-127.

Sipko J. 2012: Fragmenty jazykového obrazu našej doby v aforizmoch, ,Jazyk a kultúra“, http://www. ff.unipo.sk/jak/10_2012/sipko.pdf (prístup 29. 10. 2016).

Záborská A. 2016 (v tlači): Jazykovo-kultúrne súvislosti vo vtipoch, Bratislava.

\section{Zdroje vtipov}

Kalina J. L. 1991: Tisic a jeden vtip, Archa, Martin.

Špetko A. 2009: Zlatá kniha slovenského humoru, Espero, Partizánske.

http://vtipy.4me.sk/ (prístup 10-11 2016).

http://vtipy.zabinudu.sk/ (prístup 10-11 2016).

http://www.seniorhumor.org/?page_id=192 (prístup 10-11 2016).

http://www.smiechoty.sk/ (prístup 10-11 2016).

\section{MULTICULTURALISM AS A SOURCE OF HUMOR IN TERMS OF ONOMASTICS}

\section{SUMMARY}

The goal of the paper is to analyze the use of proper names in ethnic humour that illustrates language, cultural, and racial differences between one's own ethnic group and foreign ones. Specifically, we work with Slovak ethnic jokes in which proper names have various functions. Besides the dominant expres- 
sive function, they are used to indicate character's ethnicity - for this purpose, mainly ethnonyms are used. Sometimes anthroponyms are used in this respect as well but since their identification function is weakened, they are usually accompanied by an ethnonym (or a toponym) which helps clarify the ethnic aspect. Alongside proper names, deethnonyms are used. Ethnic humour in general may be perceived as an accompanying phenomenon of multiculturalism and globalization due to which various ethnic groups are in mutual contact. Cultural encounter is often accompanied by creation of national and ethnic stereotypes which are reflected in a language of a particular ethnic group via phrasemes as well as jokes. Bearers of such stereotypes in jokes are groups of people - ethnic groups (represented by ethnonyms) and individuals - members of an ethnic group (represented by anthroponyms which refer to respective ethnic groups). Ethnonyms and ethnicity-indicating anthroponyms, as formal bearers of ethnic and stereotypical information, refer to all members of the given ethnic group(s) and thus they serve as a pars pro toto type of synecdoche.

Key w ord s: multiculturalism, stereotype, ethnic humour, ethnonym, anthroponym 